\title{
MOŽNOST PODPORY NA REGENERACI BROWNFIELDS
}

\author{
THE POSSIBILITY SUPPORT TO BROWNFIELDS REGENERATION
}

\author{
Ing. Lukele Petra Elly; doc. Ing. Korytárová J ana, Ph.D.
}

\begin{abstract}
ABSTRAKT
Práce se v počátku zaměřuje na vysvětlení obecné charakteristiky urbanistického termínu brownfields. Vysvětluje př́činu, proč tyto lokality nemohou být podporovány z dostupných dotací, a je třeba pro efektivní rehabilitaci navrhnout nový systém, jehož princip je zde nastíněn. Cílem navrhnutého systému by bylo určení doby návratnosti vložených finančních prostř̌edků do sanace na podporu rozvoje brownfields. Tento finanční nástroj by sloužil malým a středním podnikům, ze kterého by čerpali prostředky. V textu je popsána současná analýza stavu a proveditelnost.
\end{abstract}

Klíčová slova: Analýza, brownfields, fond, financování, podpora, proveditelnost

\section{ABSTRACT}

The work focuses on issues explaine the general characteristics of urban brownfields term. The specifics reason, why these sites may not be supported by the available funding, and is neccessery create a new system for effective rehabilitation. It explores the possibilities and ways of financing these abandoned and unused areas. The aim of the paper focuses on determine the period of recovery of the investment into sanitation to support the development of brownfields. The text describes the current analysis of condition, feasibility; especially is focused on current funds to support the abandoned territory.

Keywords: Analysis, brownfields, feasibility, fund, funding, support

\section{OBECNÁ CHARAKTERISTIKA}

Brownfields je urbanistický termín označující opuštěná území, prázdné haly, dopravní stavby, letiště, průmyslové zóny, rozpadající se obytné budovy. Označení vychází z barvy opuštěných staveb na leteckých a satelitních snímcích. Opakem jsou greenfields. Brownfields jsou charakteristické často svými obrovskými rozměry, negativními sociálními a ekologické dopady, jako jsou např́íklad krádeže, shromažd’ování bezdomovců, vandalismus apod., a nesmíme opomenout jejich velkou ekologickou zátěž. Pohlédneme na brownfields z opačného úhlu pohledu, jsou v mnoha případech tvořeny kulturně a technicky cennými budovami, včetně jedinečného technologického vybavení či výstavbou. Při obnovení užívání budov se proto doporučuje přihlížet $\mathrm{k}$ těmto aspektům a pokud možno je částečně zachovat. Brownfields často představují potenciál dalšího rozvoje a jejich realizace má pozitivní sociální a ekonomický dopad na danou oblast.

Jedním z největších problémů, týkající se sanace brownfields, je potřeba investice a výše finančních prostředků nutné $\mathrm{k}$ rekonstrukci brownfields.

\subsection{Proč revitalizovat brownfield}

Výhody přestavby brownfields jsou jak environmentální, tak ekonomické. Přivedení brownfields k aktivnímu využívání se zvýší atraktivnost lokality, zvýší se hodnota sousedních pozemků, vytvoření 
se pracovní místa a lokalita bude vykazovat daňově aktivní. Zlepší se i životního prostředí, může dojít k rozšîrení zeleně a aktivního využívání krajiny. Výhodou je i využití stávající infrastruktury a především se snižuje rozléhání měst do okolí. Je třeba si uvědomit, že volný prostor není neomezený a ničme si tak krajinu.

\section{SOUČASTNOST A POČET BROWNFIELDS V ČR}

V současné době existuje Národní databáze brownfieldi̊, která obsahuje detailní informace včetně vlastnických vztahů, ekologické zátěže i fotografií ve velkém rozlišení o brownfields např́ić celou Českou republikou. Cílem regenerace je zvýšit přitažlivost a hodnotu jednotlivých lokalit na úroveň, kdy mohou přímo soutěžit $\mathrm{s}$ výstavbou na zelené louce V Národní databázi brownfieldů v současné době CzechInvest eviduje $3136 \mathrm{BF}$ z toho je 497 ve veřejném vlastnictví, $526 \mathrm{BF}$ je publikováno na webu www.brownfieldy.cz, z toho je $114 \mathrm{BF}$ ve veřejném vlastnictví. Dále je evidováno $604 \mathrm{BF}$, u nichž je kombinované vlastnictví, z toho je publikováno 23 BF.

Na základě předběžných výsledků lze odhadnout, že se na území České republiky vyskytuje asi 12000 ha brownfields. Tohle číslo ovšem není konečné a pro současnost není ani jiné k dispozici. Roku 2011 byl proveden odhad, který hovoří o čísle mezi 8500 - 11700 lokalit, zaujímají plochu až 38 tisíc hektarů. Výkyvy nastaly díky zadání a zpracování v daném kraji, a to např́klad ve velikosti minimálních ploch areálů zařazených do studie. Z toho $10 \%$ pochází z průmyslové výroby a $17 \%$ brownfields by se dalo opět využít pro průmyslovou výrobu. Přesné číslo je téměř nemožné zjistit.

Problematikou regenerace brownfields v České republice se zabývá Ministerstvo průmyslu a obchodu, Ministerstvo životního prostředí a Ministerstvo financí.

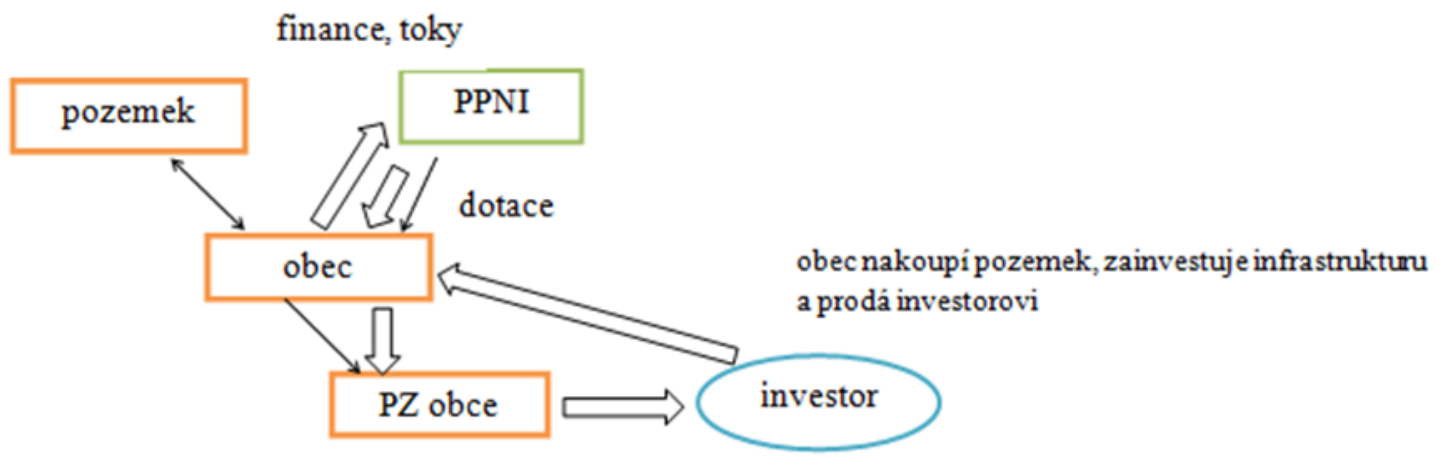

Obr. 1 Schéma Národního programu

\section{VYHLEDÁVACÍ STUDIE PRO MODEL NA REGENERACI ÚZEMÍ}

Nejvhodnějším řešením $\mathrm{k}$ sanaci brownfields je návrh vyhledávací studie modelu návratnosti a řešení financování fondu. Je třeba brát v úvahu tři možné strany. Na straně jedné soukromý sektor, a kolik by mohl zafinancovat do projektu, dále stát, a co získá obec za pozemek. Ideálním výstupem práce by byl zvolen výše úvěru pro vytvoření akciové společnosti na podporu dotčených lokalit. Výsledek bude konzultován s Ministerstvem průmyslu a obchodu České republiky a bude použit pro účely fondu pro podporu brownfields.

Jedná se například o propočítání vynaložených nákladů a posléze výše nájemného ve zrekonstruované lokalitě. Peníze se opět vloží do fondu a budou znovu použity na další regeneraci lokality. Je potřeba pečlivě zvážit dobu návratnosti. V rámci průzkumu nákladů na ekologické škody je potřeba znát procento zamořeného území z celkové plochy zóny. Prozkoumáním databáze bylo ověřeno, že 
není možné přesně odhadnout procento kontaminace průmyslových zón. Pro vyhledávající studii je nezbytné i vymezení základních kritérií, aby lokalita mohla být do ní zařazena. Do seznamu budou vloženy lokality malých velkých podniků a musí být zároveň v Národní databázi brownfieldů.

Ministerstvo průmyslu a obchodu České republiky pracuje na vývoji fondu k regeneraci brownfields:

\section{a. Struktura a složení projektového týmu}

Obsahuje návrh struktury a naplnění organizační struktury tvorby strategie, tj. především obsazení role Gestora tvorby strategie, Koordinátora tvorby strategie, složení Týmu pro tvorbu strategie a dalších rolí potřebných pro tvorbu dané strategie.

\section{b. Analýza zainteresovaných stran}

Obsahuje popis klíčových zainteresovaných stran a rámcový návrh způsobu jejich zapojení do tvorby strategie. Dále budou v této podkapitole uvedené zainteresované strany, které se budou podílet na schvalování strategie (respektive se budou podílet na samotném rozhodnutí o tvorbě strategie). Zároveň budou popsány hlavní zájmy, potřeby a priority klíčových zainteresovaných stran, které mohou ovlivnit tvorbu strategie nebo její schválení.

\section{c. Aktivity tvorby strategie}

Tato podkapitola obsahuje hlavní aktivity a činnosti (včetně indikace metod, nástrojů a technik potřebných pro jejich realizaci) potřebné pro vytvoření strategie, přičemž je u nich uveden jejich předpokládaný rozsah.

\section{d. Odhad nákladì a harmonogramu tvorby strategie}

Indikativní harmonogram a rozpočet tvorby strategie zohledňuje především nastavený rozsah a hlavní aktivity tvorby strategie.

\section{e. Havní rizika tvorby strategie}

Obsahuje popis hlavních rizik spojených s tvorbou strategie a vyhodnocení jejich významnosti (tj. jak mohou tato rizika postup tvorby strategie včetně jejího schválení ovlivnit).

Pro potřebu modelu budou lokality rozděleny do tř́ úrovní podle sanačních typů brownfields. První skupina lokality A představují rozvojové projekty, které jsou poháněné soukromým financováním. Lokality B jsou charakterizovány jako hranice rentability. Mají tendenci být financovány prostřednictvím PPP. Lokality C zahrnují projekty představující projekty zejména ve veřejném sektoru nebo obecní, poháněné veřejnými finančními prostředky nebo zvláštních právních nástrojů (např. daňové pobídky) [1].

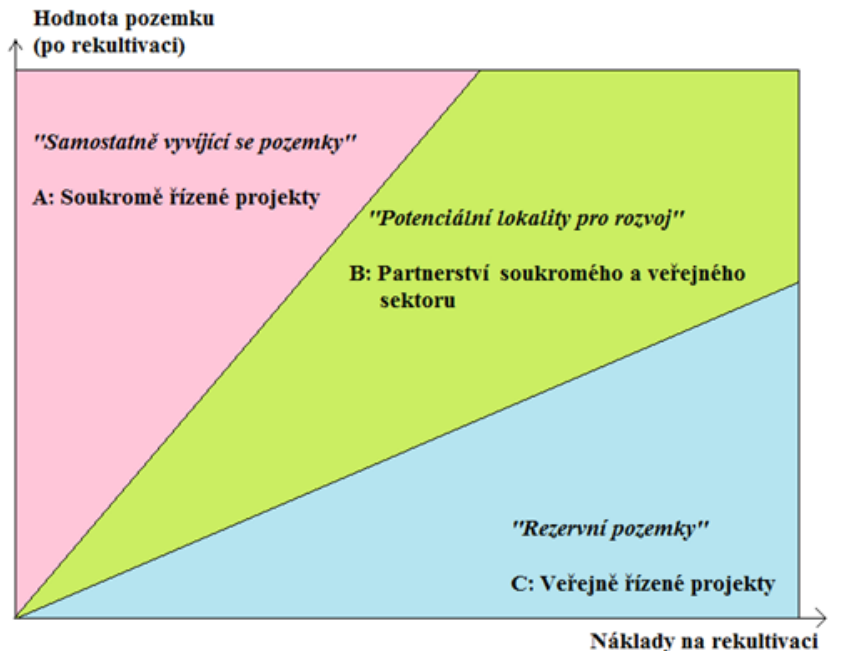

Obr. 2 Sanační typy brownfields [2] 


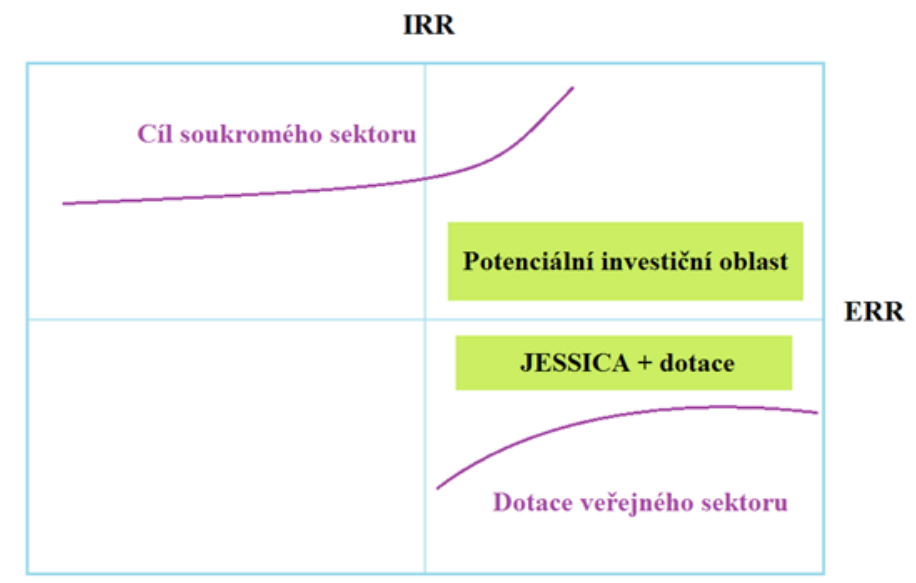

Obr. 3 Možnosti trhu [1]

\section{DÍLČí VÝSTUPY}

\subsection{Návrh modelu}

V rámci spolupráce s Ministerstvem průmyslu a obchodu bude navržen model pro zhodnocení a posouzení rentability, reálnosti a návratnosti investice do brownfields.

Tento projekt byl uskutečněn v Moravskoslezském kraji pod vedením pana Foltýnka v rámci programu JESSICA. Ministerstvo průmyslu a obchodu by chtělo zhotovit tento fond fungující pro celou Českou republiku a podporovat tím sanaci brownfields.

Strategie fondu je regenerace brownfields a výstavba infrastruktury pro podnikání. V Ostravě program probíhal tak, že společnost PPF Financial Consulting sestavila tým specialisti̊, který byl kompetentní naplnit výzvy spojené s finančními nástroji v celém životním cyklu od plánování integrované strategie rozvoje města po přípravu a realizaci konkrétního projektu. CONTERA Management je společnost vedená lidmi, kteří mají mnohaleté zkušenosti v oblasti řízení projektů, řízení stavebního procesu a rozvojem nemovitostí. Jedná se o existenci tržní mezery, kdy region severní Moravy představuje př́lišné riziko pro komerční banky, pokud se mluví o projektovém financování a podnikatelských nemovitostech. Je zde uplatněn přístup ,end - to - end“, kdy manažer fondu pracuje s projekty již v rané fázi, a to jak na straně nabídky tak i poptávky, a propojuje vlastníky, klienty a finance. Díky dalším službám, nad rámec služeb fondu dramaticky klesá „technické“ riziko financování. Moravskoslezský kraj si vybral na rozvoj EIB. Byly vypsány 2 soutěže na úvěrový program regenerace brownfields, ale nebyl funkční. V druhé byl zvolen fond a správce fondu a sbíral žádosti a předkládali se mu projekty. Tím se pak založí SPB (akciová společnost) a do ní obec vloží pozemek, SPV finance a zrealizuje se projekt. Jedná se o podobný princip jako u PPP, ale zde je problém koncesních smluv, a že vlastník je většinou developer a lidé si navzájem nevěří.

Návrh modelu bude nejprve nejprve obsahovat identifikaci a členění lokalit, poté je třeba určit dostupné dotační fondy pro daný rok. Nejdůležitejší částí modelu bude výpočet, aby lokalita byla schopna návratnosti, a za jakých podmínek nastane. Neméně významným je výpočet či odhad budoucího nájmu lokality, od kterého se doba návratnosti odvíjí. Vše se musíme dát do matematické podoby a získat potřebný vzorec. Je zapotřebí zjistit náklady na výstavbu zóny a objektu, model investic státních a soukromých prostředků, určit analýzu nákladů vynaložených na výstavbu.

Je třeba nastínit nejlepší řešení, přehlednost a správnost výpočtů, s cílem použití identifikace lokalit pro Českou republiku, a vytvoření fondu pro uskutečnění návratných akcí lokalit k životu. 


\subsubsection{Finanční nástroje $v$ Moravskoslezském kraji - alternativní forma financování městského rozvoje z prostředků EU}

Evropská komise připravila $\mathrm{v}$ rámci přípravy programového období 2007-2013 4 iniciativy, označované jako 4J - JESSICA, JEREMIE, JASPERS a JASMINE. Smyslem těchto iniciativ bylo zvýšit účinnost a udržitelnost využívání strukturálních fondů. Jedná se o finanční nástroje a technickou asistenci.

\section{JASPERS - př́íprava velkých projektů}

JASPERS, neboli „Společná pomoc při podpoře projektů v evropských regionech“, poskytuje technickou pomoc pro dvanáct zemí EU, které přistoupily v roce 2004 a 2007. Tým JASPERS nabízí pomoc při př́pravě velkých projektů, které budou spolufinancovány z EU fondů a na které jsou kladeny vysoké kvalitativní požadavky.

\section{JEREMIE - financování MSP}

JEREMIE, neboli „Společné evropské zdroje pro mikropodniky až střední podniky“, je iniciativou Evropské komise vyvinutou společně s Evropským investičním fondem (EIF). Podporuje využití finančních nástrojů s cílem zlepšit přístup k financování pro malé a střední podniky.

\section{JESSICA - podpora městského rozvoje}

JESSICA, neboli „Společná evropská podpora udržitelných investic do městských oblastí“, je iniciativa Evropské komise připravená ve spolupráci s Evropskou investiční bankou (EIB) a Radou Evropské rozvojové banky (CEB). Podporuje trvale udržitelný rozvoj měst a regeneraci pomocí finančních nástrojů.

JESSICA podporuje udržitelné městské podporou projektů například v následujících oblastech:

- městská infrastruktura - doprava, voda/odpadní vody, energie;

- kulturní památky a dědictví - cestovní ruch nebo jiné udržitelné využití;

- regenerace brownfields;

- tvorba zázemí pro malé a střední podniky, IT a/nebo R\&D;

- univerzitní kampusy;

- lepení energetické činnosti [1].

\section{Jak JESSICA funguje?}

Příspěvky z Evropského fondu pro regionální rozvoj (ERDF) jsou přiděleny fondům rozvoje měst (FRM, UDF), které je investují do partnerství veřejného a soukromého sektoru nebo do jiných projektů zahrnutých do integrovaného plánu pro udržitelný rozvoj míst. Tyto investice mohou mít formu vlastního kapitálu, úvěrů a/nebo záruk.

Alternativně může řídící orgán směrovat finanční prostředky do fondů pomocí holdingového fondu (HF), které jsou vytvořeny, aby investovali do několika FRM.

Vzhledem $\mathrm{k}$ revolvingovému charakteru nástrojů jsou výnosy z investic znovu investovány do nových projektů rozvoje měst, čímž se recyklují veřejné prostředky [1].

\section{Jaké jsou výhody využití FN}

- Udržitelnost - investice FRM by měly generovat výnosy a tímto způsobem splatit poskytnutou podporu. To nabízí udržitelnější alternativu $\mathrm{k}$ pomoci tradičně poskytované prostřednictvím dotací. 
- Pákový efekt - tím, že fond kombinuje strukturální fondy s jinými zdroji financování, bude JESSICA zvyšovat disponibilní prostředky, které jednodušeji poskytnou podporu většímu počtu projekti̊.

- Flexibilita - model JESSICA nabízí flexibilitu, a to jak z pohledu struktury, tak při využívání finančních prostř̌edků formou vlastního kapitálu, úvěru nebo záruky. Ty pak mohou být přizpůsobeny specifickým potřebám jednotlivých regionů či projektů.

- Odbornost - JESSICA umožňuje řídícím orgánům, městům a obcím, aby zapojily soukromý a bankovní sektor. To pomáhá $\mathrm{k}$ přilákání dalších investic, stejně jako technické a finanční kapacity pro řízení projektů [1].

Využití nástroje JESSICA v EU

- Připraveno 65 hodnotících studií na téma JESSICA ve 22 členských státech; 54 studií již dokončeno (http://jessica.europa.eu; www.eib.org/jessica);

- 1,89 mld. EUR formálně převedeno do 22 JESSICA schémat v 11 členských státech;

- 19 Holdingových fondů and 3 FRM bez HFm z tohi 18 řízeno EIB;

- cca 30 FRM je aktuálně vybráno, první projekty se realizují v Estonsku, Německu, Polsku a Litvě [1].

\section{Očekávání od přištího období}

- Předpokládá se zvýšení významu finančních nástrojů při využívání rozpočtových zdrojů EU (Budget review, 5th Cohesion Report, MFF 2014-2020);

- legislativní rámec pro 2014-2020 poskytne jasnou sadu pravidel, která bude založena na současné dobré praxi;

- „direct management“ - komise bude podporovat vznik centrálně řízených fondů ve správě EIB.

- rozsah - společné ustanovení v Obecném nařízení pro všechny fondy (ERDF, ESF apod.), pokrytí všech tematických cílů.

- novinka - Ex ante hodnocení zapojení FN jako povinná součást prrípravy operačního programu.

- kombinace - projekty by měly snáz získávat návratnou i dotační podporu, vždy s aplikací adekvátních pravidel pro veřejnou podporu [1].

\section{Použitá literatura}

[1] FOLTÝNEK D. (2014). Regenerace brownfields s využitím finančních nástrojů. Prezentace. [cit. 2015-10-01]

[2] CABERNET (2013). MODEL 2: Brownfield Redevelopment Types - the A-B-C Model [cit. 2015-10-07]. Dostupný z: http://www.cabernet.org.uk/index.asp?c=1312 